\title{
GENETICS AND SELECTION AT THE Ng LOCUS IN BLUE GROUSE (DENDRAGAPUS OBSCURUS)
}

\author{
J. A. REDFIELD \\ Department of Zoology, University of Alberta, Edmonton, Alberto
}

Received 17.ix.73

\section{SUMMARY}

The $\mathcal{N g}$ locus is an electrophoretically detectable polymorphism in blue grouse with three alleles widespread in birds on Vancouver Island and the adjacent mainland. Little, if any, migration occurs between populations, suggesting that the polymorphism is maintained by selection. No differences were found in reproductive output of different genotypes but survival was selective. In one year juvenile birds with the most common genotype survived better than juveniles with other genotypes. Heterozygous birds 1 year old and older survived best in 2 years with harsh winter weather. In one year with mild winter weather no differences in survival were found. Although the actual mechanism of selective death is not known, the evidence suggests that heterozygous advantage is one of the means of maintaining genetic polymorphisms. However, several other components of fitness at this locus have been found and these must also be considered in the maintenance of this polymorphism.

\section{INTRODUGTION}

STudies of genetic variation in natural populations have been greatly advanced in the past decade by development of electrophoretic techniques (Lush, 1970). It is now recognised that populations are made up of genetically heterogeneous individuals and that polymorphism is more widespread than previously thought (Harris, 1966; Lewontin and Hubby, 1966; Lewontin, 1967).

Kimura (1968, 1969), Kimura and Maruyama (1971) and Kimura and Ohta (1971) argue that most protein polymorphisms are neutral with respect to fitness and that genetic drift, mutation and migration are strong enough to maintain the same alleles over wide geographic areas. In fact, Maruyama $(1970 a, b)$ has shown that rates of migration between populations must be severely restricted if local populations are to remain genetically distinct.

On the other hand, Manwell and Baker (1970), Prakash et al. (1969) and Lewontin and Krakauer (1973) argue that polymorphisms have patterns suggesting maintenance by selection. Field evidence has accumulated recently which seems to suggest that a more critical appraisal should be given to the neutral allele hypothesis. For example, Fujino and Kang (1968) have shown differential survival among different genotypes at a transferrin locus in tunafish (Katsuwonus pelamis). Canham (1969) argued for selective survival of different genotypes at both the transferrin and albumin loci in two species of small rodents in northern Canada. Birdsall

* Present address: Institute of Animal Resource Ecology, University of British Columbia, Vancouver, B.C., Canada. 
(1972) gave some evidence for selective maintenance of three cryptic polymorphisms in Peromyscus maniculatus. Tamarin and Krebs (1969), Myers and Krebs (1971) and Gaines and Krebs (1971) also showed different demographic histories associated with different genotypes at both the transferrin and leucine aminopeptidase loci in two species of voles (Microtus ochrogaster and $M$. pennsylvanicus). Other evidence inconsistent with the neutral allele hypothesis comes from studies of cryptic enzymatic polymorphisms by Koehn and Rasmussen (1967), Koehn and Mitton (1972), Koehn et al. (1971) and Merritt (1972). While the neutral allele proposal is theoretically tenable, it seems incompatible with the evidence from field studies. Therefore, an evaluation of potential mechanisms of maintenance of a polymorphism is one of the most important topics in ecological genetics (Wallace, 1970).

The $\mathcal{N g}$ locus has three codominant alleles at a single autosomal locus. The three alleles at this locus are widespread in grouse populations on Vancouver Island and the adjacent mainland with no heterogeneity between populations, in spite of very low rates of observed movement between populations (Redfield et al., 1972). Individuals with different genotypes at the $\mathcal{N g}$ locus are selectively recruited into populations of different densities (Redfield, 1972, 1973a). This results in the most dense populations having an excess of heterozygous genotypes and the least dense ones having a significant deficiency. In addition, heterozygous mothers produce a significant excess of homozygous genotypes (Redfield, 1973b).

In this paper I examine other aspects of the dynamics of this polymorphism in blue grouse, especially selection as it affects reproduction and survival. The specific objectives of this paper are $(a)$ to present a detailed analysis of the genetic structure of the populations studied; $(b)$ to analyse fitness based on reproduction and survival; and $(c)$ to discuss the overall population structure of blue grouse populations. The data presented here are particularly pertinent to the discussion of neutral alleles since the locus used in the analysis was chosen in a haphazard manner from electrophoretically variable proteins and since the data on selection are direct estimates based on actual survival and reproduction of individually marked grouse. This direct measurement of survival and reproduction avoids some potential biases inherent in other methods of calculation of fitness (Prout, 1965).

\section{Materials AND methods}

\section{(i) Field techniques}

Blue grouse were captured from three populations in the Ash River Valley, Vancouver Island, British Columbia. Each bird was bled, individually marked with leg bands and released. In most years high proportions (70 per cent) of the individuals in each population were marked and genetically identified (Redfield, 1972, 1973a). Thus, these data approach a total enumeration rather than a random sampling. This makes the usual statistical tests potentially invalid (Neel, 1967). However, until suitable alternative tests are developed, standard statistical tests must be used to check the significance of the results. Surely this makes one more conservative and should not damage the significance of the differences which arise. 


\section{(ii) Electrophoretic techniques}

Specific details of electrophoresis and staining have been outlined in Redfield (1972). Briefly, vertical starch-gel electrophoresis of plasma was conducted in a discontinuous system of buffers (Birdsall et al., 1970). Following electrophoresis, gels were stained for esterase activity. Esterases appeared as dark blue or black areas on a grey background while the gene products of the $\mathcal{N g}$ locus appeared as white areas anodal to the major albumin esterase activity.

\section{(iii) Study areas}

Three populations of grouse were sampled in the Ash River Valley, near Port Alberni, British Columbia. All areas have been logged by clear cutting in the past 2 to 15 years. The three study areas will be referred to as 104,107 and $108 \mathrm{e}$. Area 104 is approximately $3 \mathrm{~km}$ northeast of areas 107 and 108e and is separated from these areas by an extensive tract of unsuitable habitat. Areas 107 and $108 \mathrm{e}$ are only about $\frac{1}{2}$ to $1 \mathrm{~km}$ apart, with continuous habitat in between.

Most of the natural forest in the Ash River Valley has been logged. In recent years, 15 to 40 ha stands have been logged with clear-cut techniques. Almost all of the logged areas have been replanted with Douglas fir (Pseudotsuga menziesii) and these plantations are in various stages of regeneration. Blue grouse characteristically inhabit these logged regions.

\section{BAGKGROUND}

The life history of blue grouse is well known and has been documented in a series of papers (Bendell and Elliott, 1967; Zwickel and Bendell, 1967; Redfield et al., 1970). However, some of the more pertinent life history events, i.e. those that might alter genetic events, are outlined here.

Three age classes of birds can be distinguished: (1) adults are birds 2 years old and older, (2) yearlings are birds 1 year old, and (3) juveniles are less than 6 months of age. Adults and yearlings have a high fidelity to breeding areas and individuals invariably occupy the same general breeding area each year. Juveniles, on the other hand, are the genetically mobile segment and few juveniles are found after they have been marked.

Except when mating, adult males seem to live alone on territories during the breeding season (April to August). Yearling males apparently do not participate in breeding and wander extensively in spring. However, both adult and yearling females breed. This system of mating reduces the effective population size.

In mid to late summer grouse migrate off breeding range to wintering areas, mainly in the mature forest nearby. About 50 to 70 per cent of adults and yearlings present in one year return the following year. Thus, blue grouse fit a model of discrete breeding populations with overlapping generations.

\section{Results}

Three white bands, representing three codominant alleles at a single autosomal locus $(\mathcal{N g F}, \mathcal{N g} M, \mathcal{N g S})$ have been detected at the $\mathcal{N g}$ locus in blue grouse. Homozygotes are characterised by having a single band and heterozygotes have two bands on gels following electrophoresis. $\mathcal{N g} M$ was 
always the most frequent allele and for many analyses the frequency of $\mathcal{N g F}$ and $\mathrm{NgS}$ were combined. This avoids some small observed and expected values. I have examined the allele frequencies and genotypic distributions in the three study areas, compared these distributions to those expected on the basis of Hardy-Weinberg equilibrium conditions, compared allele frequencies between populations and years and finally, calculated fitness values based on reproduction and survival of each genotype.

\section{(i) Hardy-Weinberg calculations}

Observed and expected allele and genotype frequencies for the $\mathcal{N g}$ locus were calculated for all sex and age-groups on all study areas and the totals for all years are given in table 1 . Few deviations from Hardy-Weinberg

TAble 1

Genetic parameters for the $\mathrm{Ng}$ locus in blue grouse. For computations of the goodness-of-fit to HardyWeinberg conditions, $\mathrm{NgF}$ was considered equivalent to $\mathrm{Ngs}$

\begin{tabular}{|c|c|c|c|c|c|c|c|c|c|}
\hline $\begin{array}{l}\text { Year } \\
1968\end{array}$ & $\begin{array}{l}\text { Area } \\
104 \\
107\end{array}$ & $\begin{array}{l}\mathrm{N} \\
64 \\
61\end{array}$ & $\begin{array}{l}\text { SS* } \\
0.06 \\
0.07\end{array}$ & $\begin{array}{c}\text { SM* } \\
0.03 \\
0.33\end{array}$ & $\begin{array}{c}\mathrm{MM}^{*} \\
0.64 \\
0.61\end{array}$ & $\begin{array}{r}P<\dagger \\
0.30 \\
0.48\end{array}$ & $\begin{array}{c}q \ddagger \\
0 \cdot 13 \\
0 \cdot 10\end{array}$ & $\begin{array}{c}r_{+}^{+} \\
0 \cdot 79 \\
0.77\end{array}$ & $\begin{array}{c}s_{\ddagger}^{\ddagger} \\
0 \cdot 08 \\
0 \cdot 13\end{array}$ \\
\hline 1969 & $\begin{array}{l}104 \\
107 \\
108 \mathrm{e}\end{array}$ & $\begin{array}{r}83 \\
103 \\
66\end{array}$ & $\begin{array}{l}0.05 \\
0.04 \\
0.09\end{array}$ & $\begin{array}{l}0.35 \\
0.31 \\
0.35\end{array}$ & $\begin{array}{l}0.60 \\
0.65 \\
0.56\end{array}$ & $\begin{array}{l}0.97 \\
0.86 \\
0.32\end{array}$ & $\begin{array}{l}0.14 \\
0 \cdot 12 \\
0 \cdot 21\end{array}$ & $\begin{array}{l}0.78 \\
0.81 \\
0.74\end{array}$ & $\begin{array}{l}0.08 \\
0.08 \\
0.06\end{array}$ \\
\hline 1970 & $\begin{array}{l}104 \\
107 \\
108 \mathrm{e}\end{array}$ & $\begin{array}{r}92 \\
130 \\
61\end{array}$ & $\begin{array}{l}0.05 \\
0.05 \\
0.05\end{array}$ & $\begin{array}{l}0.34 \\
0.25 \\
0.21\end{array}$ & $\begin{array}{l}0.60 \\
0 \cdot 70 \\
0 \cdot 74\end{array}$ & $\begin{array}{l}0.71 \\
0.06 \\
0.10\end{array}$ & $\begin{array}{l}0.14 \\
0 \cdot 10 \\
0.09\end{array}$ & $\begin{array}{l}0.78 \\
0.82 \\
0.84\end{array}$ & $\begin{array}{l}0.09 \\
0.07 \\
0.07\end{array}$ \\
\hline 1971 & $\begin{array}{l}104 \\
107 \\
108 \mathrm{e}\end{array}$ & $\begin{array}{r}104 \\
204 \\
81\end{array}$ & $\begin{array}{l}0.05 \\
0.03 \\
0.01\end{array}$ & $\begin{array}{l}0.39 \\
0 \cdot 27 \\
0 \cdot 25\end{array}$ & $\begin{array}{l}0.57 \\
0.70 \\
0.74\end{array}$ & $\begin{array}{l}0.65 \\
0.45 \\
0.72\end{array}$ & $\begin{array}{l}0 \cdot 14 \\
0 \cdot 10 \\
0 \cdot 10\end{array}$ & $\begin{array}{l}0.76 \\
0.83 \\
0.86\end{array}$ & $\begin{array}{l}0.10 \\
0.07 \\
0.04\end{array}$ \\
\hline
\end{tabular}

* SS, SM, and MM refer respectively to the frequencies of the genotypes $\mathcal{N g} S / \mathcal{N g} S$, $\mathcal{N g} S / \mathcal{N g} M$, and $\mathcal{N g} M / \mathcal{N g} M$.

$\dagger \mathrm{P}<$ refers to the probability based on the Hardy-Weinberg model.

$\ddagger q, r$, and $s$ refer respectively to the frequencies of the three alleles, $\mathcal{N g} S, \mathcal{N g} M$, and $\mathcal{N g F}$.

expectations (using Levene's exact test for small samples (Dobzhansky and Levene (1948)) but all significant or near significant deviations were in the direction of too few heterozygotes.

In 1971, but not in other years, allele frequencies varied between areas $\left.\chi_{(2)}^{2}=8.5, \mathrm{P}<0.01\right)$. This heterogeneity was apparently caused by a lower frequency of $\mathcal{N g M}$ in area 104 as compared with 107 or $108 \mathrm{e}$.

When combined data within areas were compared within sex and agegroups, only one difference was found. In 1969 there was a high frequency of $\mathcal{N g M}$ among yearling males $\left(\chi_{(3)}^{2}=11 \cdot 36, \mathrm{P}<0.001\right)$. Summing all data in a given year and comparing between years showed no differences.

Similar calculations to those above were done for juveniles (table 2). Since 1969, juveniles in area 104 have had a lower frequency of $\mathcal{N} g M$ than either 107 or $108 \mathrm{e}$. The frequency of $\mathcal{N g M}$ has been increasing steadily in area 108e. No differences in phenotypic ratios among juveniles on various study areas were found in 1968 or 1969, but in both 1970 and 1971 there was significant heterogeneity. This heterogeneity seemed caused by a low 
frequency of $\mathcal{N g M}$ among juveniles in area 104 as compared with 107 and $108 \mathrm{e}$.

Comparisons of phenotype frequencies within areas but between years showed significant heterogeneity in all areas $\left(104: \chi_{(3)}^{2}=10.99, \mathrm{P}<0.05\right.$; 107: $\left.\chi_{(3)}^{2}=9.17, \mathrm{P}<0.03 ; 108 \mathrm{e}: \chi_{(2)}^{2}=5.9, \mathrm{P}<0.05\right)$. In area 104 this was caused by a significant deficiency of heterozygotes in 1971; in area 107 by a low frequency of $\mathcal{N g} M$ in 1968; and in area 108 e by a low frequency of $\mathcal{N g M}$ in 1969.

TABLE 2

Genetic parametes for the $\mathrm{Ng}$ locus in juvenile blue grouse from all study areas*

\begin{tabular}{|c|c|c|c|c|c|c|c|c|c|}
\hline \multirow{3}{*}{$\begin{array}{l}\text { Year } \\
1968\end{array}$} & Area & $\mathrm{N}$ & SS & SM & MM & $\mathrm{P}<$ & $q$ & $r$ & $s$ \\
\hline & 104 & 28 & 0.04 & 0.39 & 0.57 & 0.72 & 0.09 & 0.77 & $0 \cdot 14$ \\
\hline & 107 & 13 & $0 \cdot 15$ & 0.46 & 0.39 & $0 \cdot 70$ & $0 \cdot 12$ & 0.62 & 0.27 \\
\hline \multirow{3}{*}{1969} & 104 & 20 & $0 \cdot 15$ & 0.35 & $0 \cdot 50$ & $0 \cdot 30$ & $0 \cdot 20$ & 0.62 & $0 \cdot 13$ \\
\hline & 107 & 24 & $0 \cdot 04$ & 0.21 & 0.75 & $0 \cdot 26$ & $0 \cdot 10$ & $0 \cdot 85$ & $0 \cdot 04$ \\
\hline & $108 \mathrm{e}$ & 10 & $0 \cdot 10$ & $0 \cdot 30$ & $0 \cdot 60$ & 0.27 & 0.20 & 0.75 & 0.05 \\
\hline \multirow[t]{3}{*}{1970} & 104 & 52 & 0.04 & 0.50 & 0.46 & $0 \cdot 15$ & $0 \cdot 19$ & 0.71 & $0 \cdot 11$ \\
\hline & 107 & 71 & 0.03 & $0 \cdot 35$ & $0 \cdot 62$ & 0.55 & $0 \cdot 14$ & 0.80 & 0.06 \\
\hline & $108 \mathrm{e}$ & 37 & 0.03 & $0 \cdot 08$ & $0 \cdot 89$ & 0.004 & $0 \cdot 04$ & 0.93 & 0.03 \\
\hline \multirow[t]{3}{*}{1971} & 104 & 23 & 0.22 & 0.22 & 0.57 & 0.007 & 0.20 & 0.67 & $0 \cdot 13$ \\
\hline & 107 & 23 & $0 \cdot 00$ & $0 \cdot 26$ & 0.74 & 0.56 & $0 \cdot 13$ & 0.87 & $0 \cdot 00$ \\
\hline & $108 \mathrm{e}$ & 22 & 0.00 & $0 \cdot 09$ & 0.91 & $1 \cdot 00$ & 0.02 & 0.96 & 0.02 \\
\hline
\end{tabular}

(ii) Components of fitness

Several stages in the life history of blue grouse might have differential reproduction and survival. Some of these components of selection will be analysed in this section.

Reproductive fitness was analysed in two ways: (1) genotypes of females with and without broods were compared; and (2) brood sizes were compared with maternal genotype.

Initially, genotypic frequencies of females with broods were compared with those without broods (table 3 ). No significant differences or trends were found between successful and unsuccessful breeders in any year. Nor were any differences found when adults were considered separately from yearlings or when all years were combined. It appears that successful completion of nesting is an unselective event, at least at the $\mathcal{N g}$ locus.

Comparisons of average brood size by genotype and year were done with a two-way analysis of variance with unequal and disproportionate sample sizes by the method of fitting constants (Steel and Torrie, 1960). Since adults and yearlings often have different average brood sizes (Redfield, in preparation), averages were calculated separately for adults and yearlings. The lack of significant differences or trends $(F$ (adult) $=2 \cdot 11, \mathrm{P}>0 \cdot 1$; $\mathrm{F}$ (yearling) $<1, \mathrm{P}>0.5$ ) suggests that brood size is independent of genotype in the mother. Thus, selection at the level of the $\mathrm{Ng}$ locus is not operating on reproduction events.

Survival fitness was analysed by comparing overwinter survival of juveniles and older birds in the following manner: (1) for juveniles, the observed ratio 
TABLE 3

Number of female blue grouse of each $\mathrm{Ng}$ genotype with and without a brood. The frequency of $\mathrm{NgF}$ was combined with that of $\mathrm{NgS}$

\begin{tabular}{|c|c|c|c|c|c|}
\hline Year & Age & Status & $\mathcal{N g S / N g S}$ & $\mathcal{N g S} / \mathcal{N g} M$ & $\mathcal{N g} M / \mathcal{N g} M$ \\
\hline \multirow[t]{3}{*}{1968} & Adult & $\begin{array}{l}\text { With } \\
\text { Without }\end{array}$ & $\begin{array}{l}4 \\
1\end{array}$ & $\begin{array}{r}14 \\
2\end{array}$ & $\begin{array}{r}25 \\
2\end{array}$ \\
\hline & Yearling & With & 1 & 10 & 15 \\
\hline & & Without & 0 & 3 & 12 \\
\hline \multirow[t]{4}{*}{1969} & Adult & With & 3 & 18 & 30 \\
\hline & & Without & 2 & 8 & 16 \\
\hline & Yearling & With & 5 & 17 & 26 \\
\hline & & Without & 2 & 8 & 21 \\
\hline \multirow[t]{4}{*}{1970} & Adult & With & 6 & 23 & 57 \\
\hline & & Without & 2 & 6 & 13 \\
\hline & Yearling & With & 1 & 15 & 36 \\
\hline & & Without & 2 & 3 & 13 \\
\hline \multirow[t]{4}{*}{1971} & Adult & With & 3 & 23 & 68 \\
\hline & & Without & 1 & 4 & 7 \\
\hline & Yearling & With & 3 & 31 & 64 \\
\hline & & Without & 2 & 8 & 23 \\
\hline \multirow[t]{4}{*}{ Total } & Adult & With & 16 & 78 & 180 \\
\hline & & Without & 6 & 20 & 38 \\
\hline & Yearling & With & 10 & 73 & 141 \\
\hline & & Without & 6 & 22 & 69 \\
\hline
\end{tabular}

of each genotype in year $t$ was used as the expectations among yearling birds in year $\mathrm{t}+1$. This assumes that yearlings in year $t+1$ are a random sample of the population of juveniles sampled in year $t$. Any deviations should indicate selection. (2) For older birds, overwinter survival of each genotype was calculated directly by following the return rate of individually tagged birds. Fitness $(W(i j))$ for each genotype $(i j)$, was calculated using the relationship:

$$
W(i j)=(O(i j)) / E(i j))
$$

where $O(i j)$ and $E(i j)$ are the observed and expected proportions, respectively, among genotypes $i j$. All fitness values were standardised to the most fit genotype having a fitness of 1 . For juveniles, the significance of these values was tested using Chi square goodness of fit tests on the observed and expected proportions. For older birds, significance was tested with contingency Chi square analysis using the genotypes of birds which lived compared with those that disappeared.

As shown in table 4, there were no differences in survival of juveniles in the years $1969-70$ or 1970-71. But, survival in 1968-69 favoured the most common homozygote, $\mathcal{N g} M / \mathcal{N g} M$.

Among older birds, the general pattern of survival was for rare homozygous genotypes, $\mathrm{NgS} / \mathrm{NgS}$, to survive poorest and for heterozygotes to survive best (table 5 ). This trend was strongest in years with severe winter weather. The winters of 1968-69 and 1970-71 were severe, with the former being one of the coldest on record. In contrast, the winter 1969-70 was mild. Significant differences in survival occurred in years with severe winters but not in the one year with mild winter weather. 
TABLE 4

Over winter survival of juveniles by genotype

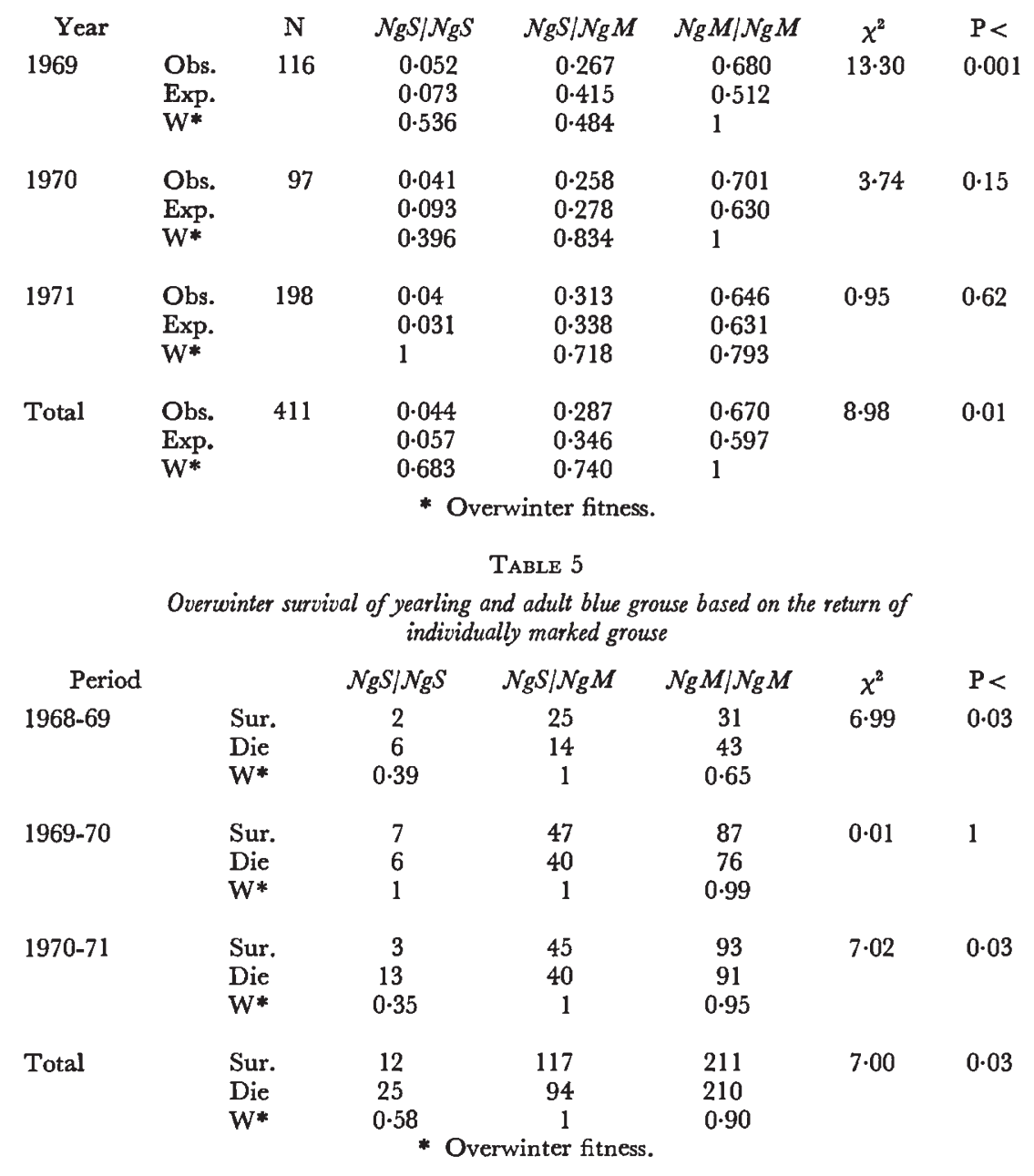

\section{Discussion}

Two important questions arise when considering data presented here: (1) why are the same three alleles found in approximately the same frequencies over relatively extensive areas?; and (2) why is there heterogeneity in allele frequencies when smaller sub-areas are considered independently? This seems to be the problem of balancing dispersive forces against stabilising ones. The lack of geographic variation in allele frequencies (Redfield et al., 1972) suggests that selection must be operating on the $\mathrm{Ng}$ locus. The variation in allele frequencies within smaller regions suggests that selection is not always strong enough to overcome dispersive forces.

Blue grouse are polygamous with one male potentially breeding with many females. Also, populations undergo significant fluctuations in numbers associated with habitat changes (Bendell and Elliott, 1966; Redfield $e$ t al., 1970; Redfield, 1973b). Generations overlap and the distribution of offspring 
seems to be non-random. These factors make the effective population size smaller than the census counts. A reduction in effective populations size can only increase the variance in gene frequencies between populations (Cavalli-Sforza and Bodmer, 1971).

Given the evidence available for blue grouse, I feel that one must conclude either that the polymorphism at the $\mathrm{Ng}$ locus is maintained by selection or that the $\mathcal{N g}$ locus is linked in a co-adapted gene complex. Selection involves at least the following components: (1) selection against heterozygous genotypes from heterozygous mothers (Redfield, 1973b); (2) selective recruitment of heterozygotes into dense populations (Redfield, 1973a); (3) selection occasionally favouring homozygous genotypes in the first year of life; and (4) selective survival of heterozygous genotypes older than one year, especially in years with harsh winter weather. Both the non-constant selection and the complexity of the selective events seem to preclude rigorous math $:$ ratical definition of equilibrium conditions.

Although the agents of genetic death in these populations are not known, it is clear that, as in the studies of Koehn et al. (1971), survival can be a function of genotype at a cryptic genetic locus. Perhaps Kimura (1971) anticipated such evidence against the neutral allele hypothesis when he stated that ". . . the amino acid changes that can be detected by electrophoretic methods may have a higher chance of affecting the physiological function of the enzyme than those which cannot be detected in this way, and therefore have a smaller chance of being neutral ". A suitable approach in future studies should combine experiments with both the demographic rigor of Krebs et al. (1969), and the extensiveness of Selander et al. (1969). It is through exhaustive population experimentation that we will begin to understand the maintenance of persistent polymorphisms.

While these data show some evidence for selection, it is still possible that this polymorphism is neutral. Suppose that the $\mathcal{N g}$ locus is neutral but located on a chromosome with other overdominant loci. Then we would expect some degree of " associative overdominance" to be expressed by the intrinsically neutral $\mathcal{N g}$ locus (Ohta and Kimura, 1971). With the data I have there is no way of determining the effects of associative overdominance. However, because of the magnitude of the selection it seems doubtful that the locus is neutral. Although selection of this magnitude, if found for many loci, might add up to a large genetic load under certain models, it is no more difficult to invoke this large load than it is to argue that these data have arisen by chance.

Acknowledgments.-Drs D. A. Birdsall, J. H. Myers and F. C. Zwickel read and commented on various drafts of this manuscript. F. C. Zwickel also aided in many other ways. M. Miller, H. Hurtak, W. Etherington, L. Everett, R. Gibson and D. Larson assisted in the field. Financial support was obtained from the American Ornithologists Union (Josselyn Van Tyne Memorial Grant), the University of Alberta and the National Research Council of Canada. My wife, Ann, provided editorial assistance. Deepest appreciation is extended to these persons and agencies.

\section{References}

Bendell, y. F., AND Elliot, P. W. 1966. Habitat selection in blue grouse. Condor, 68, 431-446.

BENDELL, J. F., AND ELLIOT, P. W. 1967. Behaviour and the regulation of numbers in blue grouse. Can. Wildl. Report Series, No. 4. 
BIRDSALL, D. A. 1972. Allele and phenotype frequency variation of three loci in natural populations of deer mice (Peromyscus maniculatus). Unpublished Ph.D. Thesis, University of Alberta.

BIRDSALL, D. A., REDFIELD, J. A., AND GAMERON, D. G. 1970. White bands on starch-gels stained for serum esterase activity: a new polymorphism. Biochem. Genet., 4, 655-658.

CANHAM, R. P. 1969. Serum protein variation and selection in fluctuating populations of Cricetid rodents. Unpublished Ph.D. Thesis, University of Alberta.

CAVAlli-sforzA, L. L., AND Bodmer, w. F. 1971. The Genetics of Human Populations. 965pp. W. H. Freeman, San Francisco.

Dobzhansky, T., AND LEVENe, H. 1948. Genetics of natural populations. XVII. Proof of operation of natural selection in wild populations of Drosophila pseudoobscura. Genetics, $33,537-547$.

FUJINO, K., AND KANG, T. 1968. Transferrin groups of tunas. Genetics, 59, 79-91.

GAINES, M. S., AND KREBS, c. J. 1971. Genetic changes in fluctuating vole populations. Evolution, 25, 702-723.

HARRIs, H. 1966. Enzyme polymorphisms in man. Roy. Soc. B., Proc., 164, 298-310.

KIMURA, M. 1968. Genetic variability maintained in a finite population. Due to mutational production of neutral or nearly neutral isoalleles. Genet. Res., 11, 247-269.

KIMURA, M. 1969. The number of heterozygous nucleotide sites maintained in a finite population due to the steady flux of mutations. Genetics, 61, 893-903.

KIMURA, M. 1971. Theoretical foundations of population genetics at the molecular level. Theor. Pop. Biol., 2, 174-208.

KIMURA, M., AND MARUYAMA, T. 1971. Pattern of neutral polymorphism in a geographically structured population. Genet. Res., 18, 125-131.

kimura, M., AND ohta, T. 1971. Theoretical Aspects of Population Genetics. 219pp. Princeton University Press, Princeton.

KoEhn, R. K., AND MrTton, J. B. 1972. Population genetics of marine pelecypods. I. Ecological heterogeneity and evolutionary strategy at an enzyme locus. Amer. Natur., 106, 47-56.

KOEHN, R. K., PEREZ, J. E., AND MERRITT, R. B. 1971. Esterase enzyme function and genetical structure of populations of the freshwater fish, Notropis stramineus. Amer. Natur., 105, 51-70.

KoeHN, R. K., AND RASmussen, D. I. 1967. Polymorphic and monomorphic serum esterase heterogeneity in catostomid fish populations. Biochem. Genet., $1,131-144$.

kREBS, G. J., KELler, B. L., AND TAMARIN, R. H. 1969. Microtus population biology: demographic changes in fluctuating populations of $M$. ochrogaster and $M$. pennsylvanicus in Southern Indiana. Ecology, 50, 587-607.

Lewontin, R. C. 1967. Population genetics. In Annual Review of Genetics, pp. 37-70.

LEWONTIN, R. G., AND HUBBy, J. L. 1966. A molecular approach to the study of genic heterozygosity in natural populations. II. Amount of variation and degree of heterozygosity in natural populations of Drosophila pseudoobscura. Genetics, 54, 595-609.

LEWONTIN, R. C., AND KRAKAUER, J. 1973. Distribution of gene frequency as a test of the theory of selective neutrality of polymorphisms. Genetics, 74, 175-195.

LUSH, I. E. 1970. The extent of biochemical variation in mammalian populations. In R. J. Berry and H. N. Southern (editors), Variation in Mammalian Populations, pp. 43-71. Zool. Soc. Lond., Symp. 26. Academic press, New York.

manWell, C., AND Baker, c. M. A. 1970. Molecular Biology and the Origin of Species. 394 pp. University of Washington Press, Seattle.

MARUYAMA, T. $1970 a$. On the fixation probability of mutant genes in a subdivided population. Genet. Res., 15, 221-225.

MARUYAMA, T. $1970 b$. On the rate of decrease of heterozygosity in circular stepping-stone models of populations. Theor. Pop. Biol., 1, 101-119.

MERRITT, R. B. 1972. Geographic distribution and enzymatic properties of lactate dehydrogenase allozymes in the fathead minnow, Pimephales promelas. Amer. Natur., $106,173-184$.

MYERS, J. H., AND KREBS, C. J. 1971. Genetic, behavioral and reproductive attributes of dispersing field voles Microtus pennsylvanicus and Microtus ochrogaster. Ecol. Monogr., 41, 53-78.

NEEL, J. v. 1967. The genetic structure of primitive human populations. Fap. 7. Hum. Genet., 12, 1-16.

OHTA, T., AND KIMURA, M. 1971. Behavior of neutral mutants influenced by associated overdominant loci in finite populations. Genetics, 69, 247-260. 
PRAKASH, s., LEWONTIN, R. C., AND hUBBy, J. L. 1969. A molecular approach to the study of genic heterozygosity in natural populations. IV. Patterns of genic variation in central, marginal and isolated populations of Drosophila pseudoobscura. Genetics, 61, 841-858.

PRouT, T. 1965. The estimation of fitnesses from genotypic frequencies. Evolution, 19, 546-551.

REDFLELD, J. A. 1972. Demography and genetics in colonizing populations of blue grouse (Dendragapus obscurus). Ph.D. Thesis, University of Alberta.

REDFIELD, J. A. 1973a. Demography and genetics in colonizing populations of blue grouse (Dendragapus obscurus). Evolution, 27, 576-592.

REDFIELD, J. A. 1973b. The use of incomplete family data in the analysis of genetics and selection at the $\mathcal{N g}$ locus in blue grouse (Dendragapus obscurus). Heredity, 31, 35-42.

REDFIELD, J. A., ZWICKEL, F. C., AND BENDELL, J. F. 1970. Effects of fire on numbers of blue grouse. Ann. Tall Timbers Fire Ecol. Conf., Proc., 10, 63-83.

REDFIELD, J. A., ZWICKEL, F. C., BENDELL, J. F., AND BERGERUD, A. T. 1972. Temporal and spatial patterns of allele and genotype frequencies at the $\mathcal{N g}$ locus in blue grouse (Dendragapus obscurus). Can. 7. Zool., 50, 1657-1662.

SELANDER, R. K., YANG., AND HUNT, W. G. 1969. Polymorphisms in esterases and haemoglobin in wild populations of the house mouse (Mus musculus). Studies in Genetics. V. Univ. Texas Publ., pp. 271-338.

Steel, R. G. D., AND TORRIE, J. H. 1960. Principles and Procedures of Statistics. 481 pp. McGrawHill, Toronto.

TAMARIN, R., AND KREBS, c. J. 1969. Microtus population biology. II. Genetic changes at the transferrin locus in fluctuating populations of two vole species. Evolution, 23, $183-211$.

wallace, B. 1970. Genetic Load. 116 pp. Prentice-Hall, Englewood Cliffs, N.J.

zWICKEL, F. C., AND BENDELL, J. F. 1967. Early mortality and the regulation of numbers in blue grouse. Can. J. Zool., 45, 817-851. 